\title{
Strategies to Improve Water Productivity in Small Tank System: A Case Study from Kurunegala District in Sri Lanka
}

\author{
K.R. Thilakasiri", G.M.P. Kumara, L.W. Galagedara ${ }^{1}$ and M.I.M. Mowjood ${ }^{1}$ \\ Postgraduate Institute of Agriculture \\ University of Peradeniya \\ Sri Lanka
}

\begin{abstract}
The number of presently operating small tanks in the Kurunegala district is 4,482 of which 2873 tanks have less than 6 ha of command area. Capacity of these tanks is low and the amount of water stored is not sufficient to fulfil the water requirement of the rice crop throughout the cropping season. Many farmers in Udakadawala area in the Kurunegala district adopts to start land preparation (LP) after filling tanks and start LP using tank water. This situation results in the delaying of the cultivation and limiting the use of rain water during the initial stages of the crop. On the other hand, due to high variability of rainfall, severe crop damages are frequently experienced. The objectives of this study were to identify the factors affecting low water productivity and to introduce and evaluate a new land and water management approach to increase rice yields. A trans-disciplinary research methodology was used employing participatory research tools. Seedling broadcasting (parachute) method with proper LP technology, time of cultivation, water management practices and use of good quality seed paddy were applied to five separate plots in the field while other fields were under their normal activities. Yield components data were collected and were analyzed. According to the results obtained, farmers delayed LP until water issue from the tank and cultivation is mainly done by rotavators mounted to two wheel tractors. In treatment, early LP with onset of rainfall using four wheel tractors save water up to $66 \%$ of the total water requirement. LP using tine tiller compared to rotavator reduces the amount of water required for the LP and increase the access to more water and nutrients by increasing the root depth. Tank water productivity was 1.93 and $0.28 \mathrm{~kg} / \mathrm{m}^{3}$ in treatment and control, respectively. The effect is more useful in Yala than in the Maha season. "Parachute" method and other agronomic practices such as recommended seeds, using organic matter, proper weeding is important along with land and water management. Conjunctive use of rainfall and tank water in combination with other management techniques was successful in increasing water productivity in small tank irrigation system.
\end{abstract}

Keywords: Conjunctive use, land preparation, small tank, tillage, water productivity

\section{INTRODUCTION}

Tank cascades, an interconnected serious of small tanks, is considered as a unique irrigation system that has been practiced in the dry zone (DZ) and intermediate zone (IZ) (Madduma Bandara, 1985). These minor tank systems play a major role in the livelihood, income generation and employment in the rural context. Water stored in these small tanks are used

\footnotetext{
1 Department of Agricultural Engineering, Faculty of Agriculture, University of Peradeniya, Peradeniya, Sri Lanka

* Corresponding author: thilakasiri@yahoo.com
} 
for irrigation as well as for other uses such as drinking water for human and animals, sanitation and hygiene and other domestic uses (Panabokke, 1999).

Majority of rice farmers in Kurunegala district cultivate paddy under minor tanks systems . Sixty five percentages (65\%) of tanks in the Kurunegala district fall within the size-class of less than 6 ha command area (DoAD, 1991). Water storage capacities of tanks are low due to their size and/or severe siltation. Therefore water management (WM) is more important to minimize water wastages during the cultivation period.

Dharmasena (1989) reported that many paddy farmers under minor tanks do not properly use rain water for land preparation (LP) and wait for water issues from tanks to begin LP. If rain is not available at later stages or less water in the tank, farmers cannot irrigate paddy fields resulting severe crop damages due to moisture stress. The highest water use is for LP compare to other agronomic practices. Therefore LP with onset of rainy season would be another option to overcome this problem. However, the ploughing tools and method of crop establishment should be selected based on the moisture content in the soil at the onset of rainfall (RF).

This study was conducted to identify and analyze the factors affecting low water productivity (WP) of rice cultivation under Udakadawala Mahawewa small irrigation scheme and to introduce and evaluate the new "Parachute" method (PM), LP and WM approach to maximize the paddy yield with reducing of water wastages.

\section{METHODOLOGY}

This study was conducted in Mahawewa tank (MWT) and three other small village tanks in the same cascade named "Gal wewa" (GWT), "Bemmulle wewa" (BWT) and "Haba wewa" (HWT) in Paduwasnuwara Agrarian Service area in the Kurunegala district. The data collection continued for 6 consecutive seasons from Maha 2010/11 to Maha 2012/13. A trans-disciplinary approach using standard participatory research tools (Samgar, 2010) such as transect, topical resource mapping, time line, matrix ranking, key informant interviews (KII) and questionnaire survey were used to identify issues and problem in paddy cultivation and WP.

\section{Measurement of RF and water issues}

Daily RF, water issues, and tank water levels were measured from $1^{\text {st }}$ November 2010 to $15^{\text {th }}$ February 2013. Water issues were measured using a Replogle, Bos, Clemmens (RBC) flume installed in the main channel. Staff gauge was installed in the tank closer to the sluice gate. A non-recording type rain gauge was installed closer to the tank.

\section{Adoption of LP and WM practices}

Four wheel tractor with tine tillers was used for primary LP in MWT farmers instead of two wheel tractor with rotavators. The time of cultivation, number of water issues, sown and harvested land extend were measured in all four tanks for comparison. 


\section{Adoption technology package (ATP) and normal practice}

ATP was used as the treatment (in MWT) while normal farmer practice was used as the control as a solution for the identified problems in the cascade. The main features of the ATP were LP with tine tiller and PM of crop establishment (CE) as shown in table 1. The field trial was conducted using randomized complete block design with 5 replicates in MWT with the plots size of $10 \times 10 \mathrm{~m}$.

Table 1. Agronomic practices adopted in treatment and control

\begin{tabular}{lll}
\hline Practice & Treatment (ATP) & Control (normal practice) \\
\hline $\begin{array}{l}\text { 1. Method of CE } \\
\text { 2. Seed paddy }\end{array}$ & $\begin{array}{l}\text { PM (Seedling broadcasting) } \\
\text { Certified seeds (Bg 300) }\end{array}$ & $\begin{array}{l}\text { Seed sowing } \\
\text { Their own seeds (Bg 300) } \\
\text { from previous harvest }\end{array}$ \\
3. LP & $\begin{array}{l}\text { Primary tillage with tine tiller mounted } \\
\text { on four wheel tractors }\end{array}$ & $\begin{array}{l}\text { Primary tillage with rotavator } \\
\text { with two wheel tractors } \\
\text { Paddy straw, green leaves and burned }\end{array}$ \\
$\begin{array}{ll}\text { 4. Organic matter } \\
\text { Paddy husk (bio char) }\end{array}$ & From primary LP \\
\hline 5. Water issues & After vegetative phase of the crop & Faddy \\
\hline
\end{tabular}

Time of cultivation: Time of cultivation was advanced from the normal practice by starting the primary LP with onset of RF without using tank water in MWT.

Method of seedling broadcast: PM was introduced instead of seed broadcasting. The nursery was established in the field on 26 October 2012 and seedlings were broadcasted after 14 days. This practice was done in 2012-2013 Maha season in five plots.

Estimation of the productivity of tank water: Sown extend and the harvested extend were recorded under both systems. Crop losses were compared for different seasons. The WP in treatment and control was separately estimated by using yield data and tank water issue. RF water was not accounted since both systems received the same RF.

Measurement of yield components: Yield components were measured from five randomly selected locations in each plot. The data was analyzed using General Leaner Model (GLM) procedure in SAS statistical software. Mean separation was conducted using Least Significant Difference (LSD).

\section{RESULTS AND DISCUSSION}

According to information gathered from farmers during Key Informant Interview (KII) and questionnaire survey, water scarcity in the Yala season is the critical problems in this area. Out of 10 farmers interviewed, 8 farmers have reported that water scarcity in Yala season was more crucial than Maha season.

\section{Time and method of LP on water saving}

Table 2 shows the water issues from tanks for continuous 6 seasons from Yala 2010. Water issues in MWT in Maha 2010/11 were identical with other tanks. All farmers in all four tanks used tank water for LP. After changing the LP strategy in MWT in 2011 Yala onwards, 
no tank water was used for LP instead started the LP using tine tiller with four wheel tractors at the onset of RF. This strategy helped to save water in the tank to use in latter stage of the growing season. However, farmers in other three tanks waited for water issues from tanks to do the primary LP using rotavators with two wheel tractors. Conversely, with advancing the LP with the onset of RF under MWT, the first 2 water issues had been saved and made available during the tail end of season.

Table 2. Water issues in four tanks of the cascade during the cropping season

\begin{tabular}{lllll}
\hline \multicolumn{1}{c}{ Season } & MWT & GWT & BWT & HWT \\
\hline 2010 Yala & 1234 & 1234 & 1234 & 1234 \\
2010-2011 Maha & 1 & 1 & 1 & 1 \\
2011 Yala & 3456 & 1234 & 1234 & 1234 \\
2011-2012 Maha & 3456 & 1234 & 1234 & 1234 \\
2012 Yala & 3456 & 1234 & 1234 & 1234 \\
2012-2013 Maha & 3456 & 1234 & 1234 & 1234 \\
\hline
\end{tabular}

Note: 1-LP; 2- at two weeks age; 3 -at four weeks age; 4- at six weeks age; 5 - three days before flowering; 6- one week after flowering

\section{RF pattern and water issues}

Fig. 1 to 5 show the tank water level, RF and time of LP, CE and $\mathrm{H}$ variation in all four tanks with days after season start. There was no severe water stress condition for paddy cultivation in all four tanks in 2010-2011 Maha season. Farmers started LP in the mid November and $\mathrm{CE}$ at the end of November. Tank water height was at full supply level $(200 \mathrm{~cm})$ and harvesting was done at the end of February.

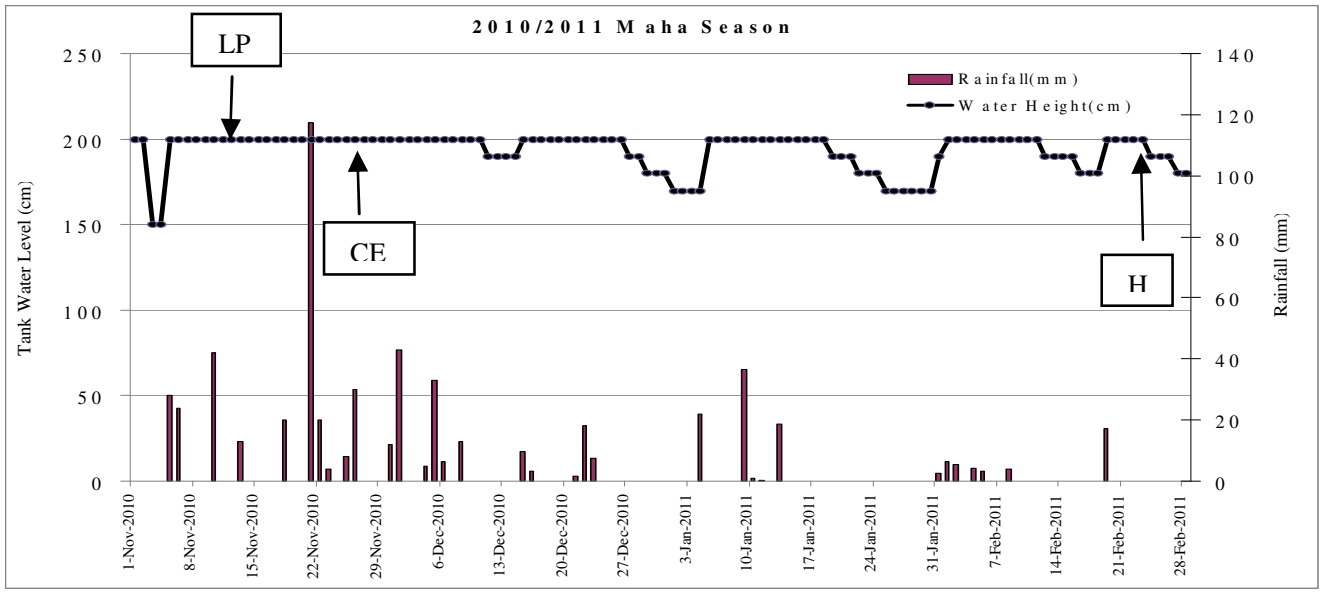

\section{Fig. 1. RF and water level of MWT during the Maha season of 2010/2011}

As shown Fig. 2, MWT farmers started LP at the mid-March and the CE was done at the first week of April in the 2011 Yala season. Farmers of the other tanks started LP at the second week of April followed by $\mathrm{CE}$ at the end of April. Due to this delayed cultivation, farmers in other three tanks faced dry field conditions from end of May where the crop was only one 
month old. However, MWT farmers' fields did not face the dry field condition since they had done CE early to keep adequate water in the tank for latter stage of the crop.

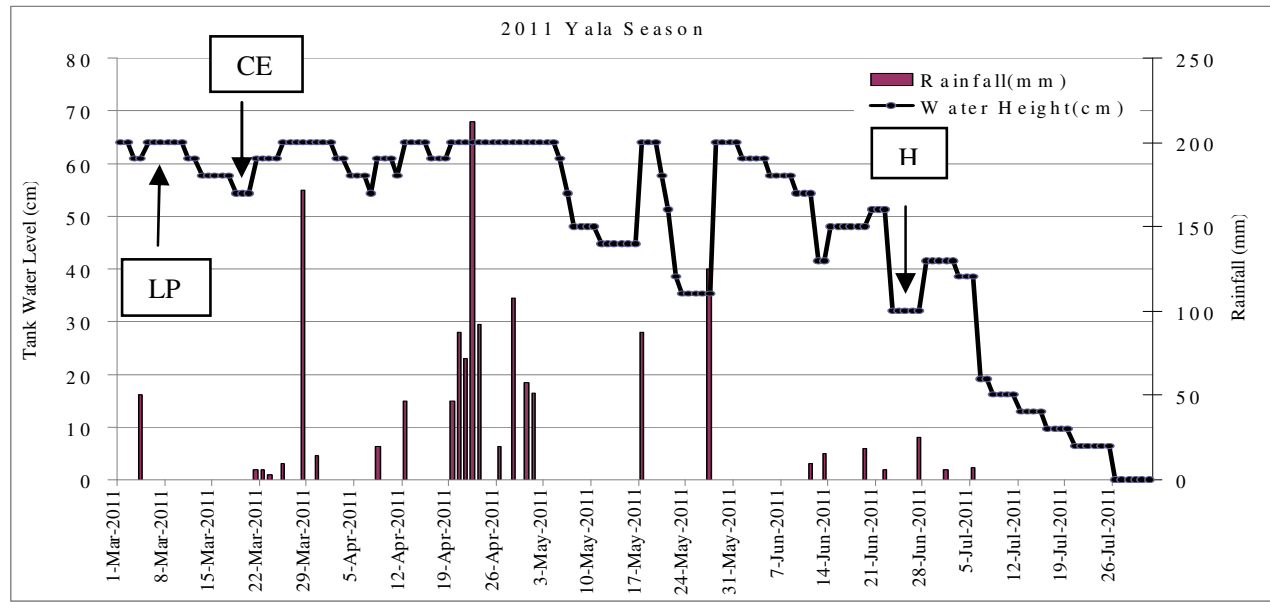

Fig. 2. RF and water level of MWT during the Yala season of 2011

As shown in Fig. 3, during the 2011/2012 Maha season, there were not adequately enough rain water after $3^{\text {rd }}$ December. MWT farmers started LP during the first week of October and $\mathrm{CE}$ was done at the end of October. Therefore they did not face severe drought condition. Farmers of the other three tanks started LP during the $2^{\text {nd }}$ week of November and CE was done at the end of November. Since there were no rains from $24^{\text {th }}$ December to $4^{\text {th }}$ February, crop faced severe drought conditions at the age of one month.

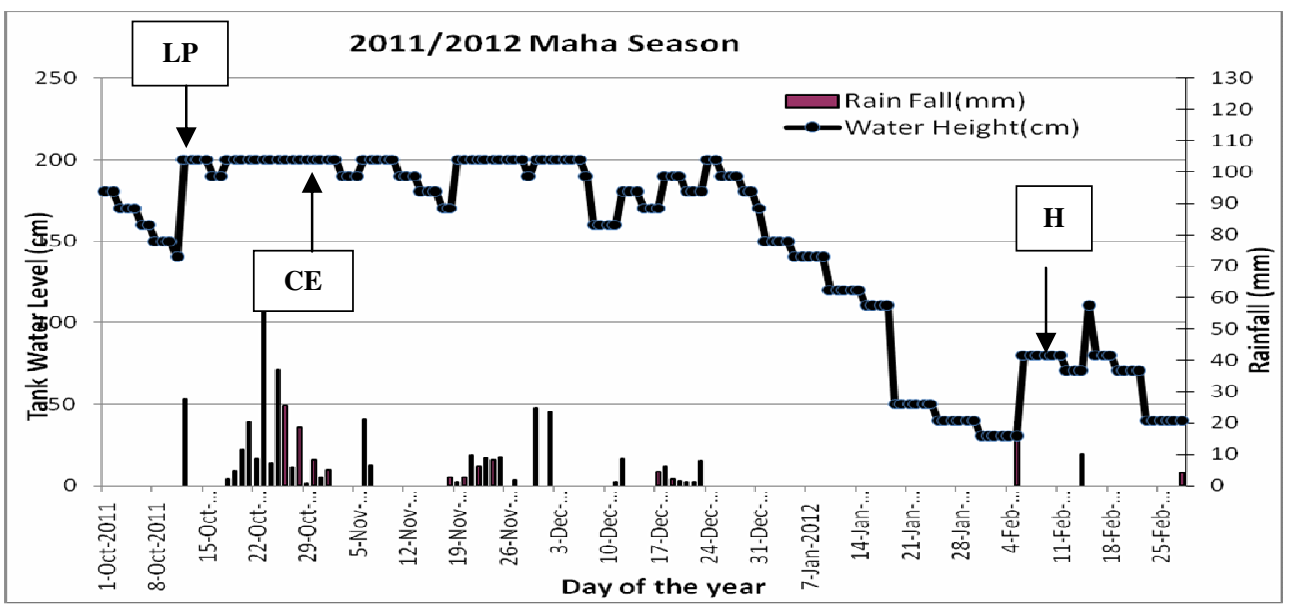

Fig. 3. RF and tank water level of MWT during the Maha season of 2011/2012

Fig. 4 shows the LP, CE and H during the 2012 Yala season. MWT farmers started LP at end of the March and seed sowing was done at the second week of the April. Farmers of the other tanks started LP during the third week of April and seed sowing was done at the end of April. Due to the delaying of cultivation, they faced drought condition from the mid May where the 
crop was at two weeks age. Conversely, MWT farmers also faced the drought condition in mid-May, but the crop was one month old and able to irrigate three times thereafter.

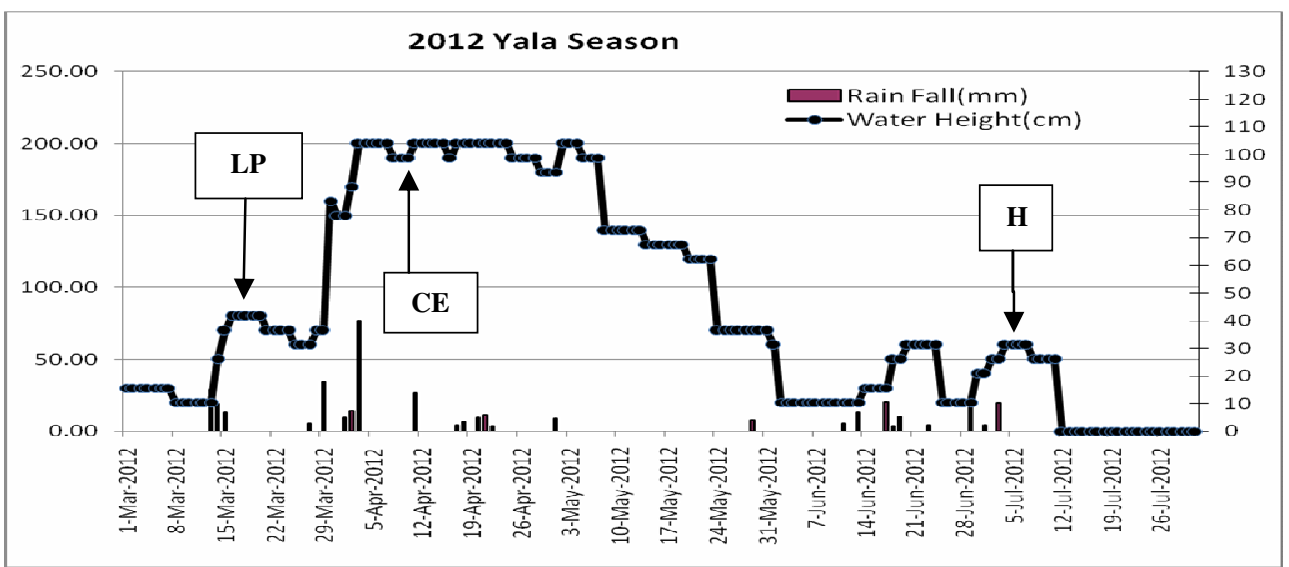

Fig. 4. RF and tank water level of MWT during the Yala season of 2012

2012/2013 Maha season (Fig. 5) there was good distribution of RF from $15^{\text {th }}$ October and did not faced water stress condition under all four tanks.

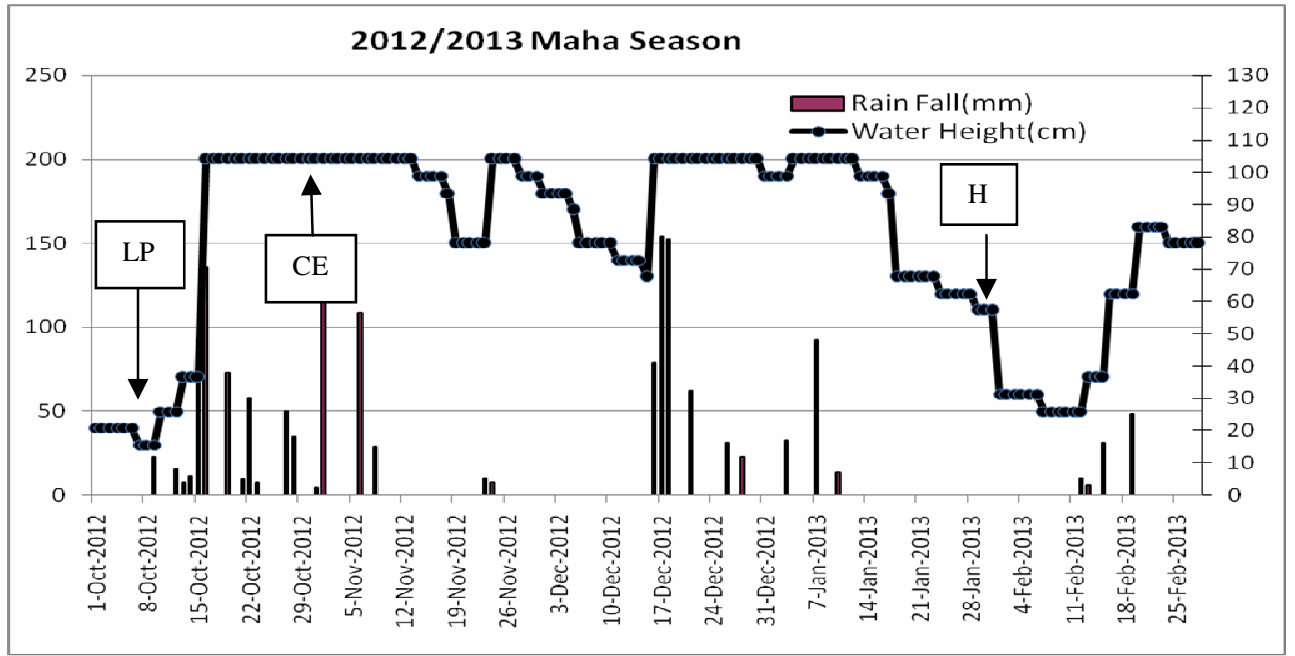

Fig. 5. RF and tank water level of MWT during the Maha season of 2012/2013

\section{Effectiveness of the time of $\mathrm{CE}$ and cultivation in water saving}

During 2010 Yala season high yield losses were recorded in all four tanks as shown in Table 3 prior to study period. No crop losses were recorded in any tank in the 2010-2011 Maha season and the 2012-2013 Maha season due to receiving of adequate RF. After introducing the ATP the harvested percentage was higher in MWT than the other tanks during water scarcity situation. 
The harvest success percentage between MWT and other three tanks in Yala and Maha seasons separately were compared and shown in Fig. 6. It was found that harvest success was more than $86 \%$ in MWT compared to other three tanks $(71 \%)$ in the Yala season. These results reveal that the method of LP and time of cultivation are very much important in obtaining higher harvest success in the Yala season for paddy cultivation under minor tanks.

Table 3. Comparison of harvested percentages in different tanks during the study period

\begin{tabular}{lcccc}
\hline \multicolumn{1}{c}{ Season } & MWT & GWT & BWT & HWT \\
\hline 2010 Yala & 70.5 & 43.7 & 65 & 56.2 \\
2010-2011 Maha & 100 & 100 & 100 & 100 \\
2011 Yala & 100 & 88 & 80 & 81.1 \\
2011-2012 Maha & 100 & 88 & 80 & 75 \\
2012 Yala & 88.2 & 55 & 60 & 37.5 \\
2012 -2013 Maha & 100 & 100 & 100 & 100 \\
\hline
\end{tabular}

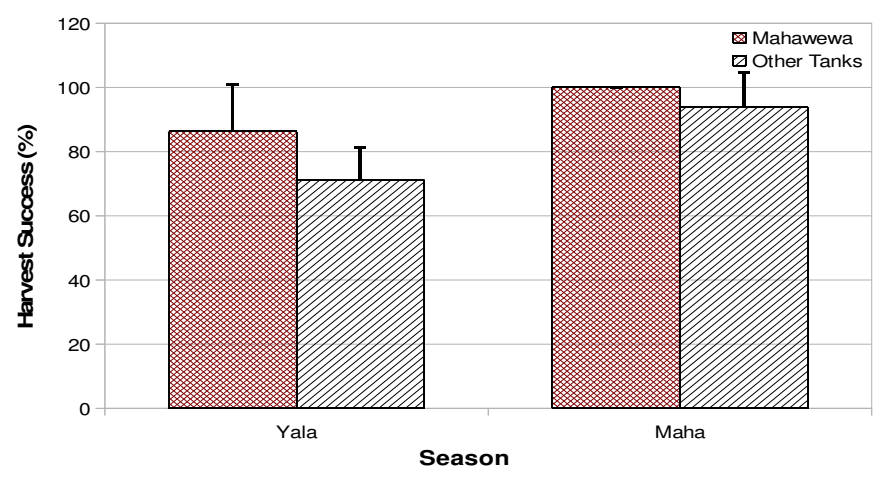

Fig. 6. Comparison of harvest success in MWT and three other tanks during Maha and Yala seasons

\section{Evaluation of PM with management practices}

Table 4 shows the yield components in treatment and control. Accordingly, the number of tillers per square meter is not significantly different while other components significantly varies $(\mathrm{P}=0.05$ level). Though the numbers of tillers are not significantly different the numbers of panicles are high under the treatment due to less water scarcity and weed competition. Average yield of the treatment $(5775 \mathrm{~kg} / \mathrm{ha})$ was significantly higher $(\mathrm{P}=<0.0001)$ than the control $(2561 \mathrm{~kg} / \mathrm{ha})$.

Under the treatment, farmers used only 2 water issues from the tank while under the control farmers used 6 water issues. Early LP with onset of RF and use of PM save 66\% of water from the tank of the season. Depth of water per issue was $75 \mathrm{~mm}$. Tank WP of the treatment is $1.93 \mathrm{~kg} / \mathrm{m}^{3}$ while it was $0.28 \mathrm{~kg} / \mathrm{m}^{3}$ in the control. The tank WP in treatment is 7 times higher than the control. These results clearly show that land and WP can be increased significantly under minor tanks irrigation systems if proper LP techniques, cultivation with onset of RF, WM, better seed paddy and planting methods are used. 
Table 4. Comparison of yield components between treatment and control

\begin{tabular}{lll}
\hline Yield component & Treatment & Control \\
\hline Number of tillers/m & & $26 \mathrm{a}( \pm 7.30)$ \\
Number of panicles/plant & $18 \mathrm{a}( \pm 2.17)$ & $4 \mathrm{~b}( \pm 1.50)$ \\
Number of grains/panicle & $8 \mathrm{a}( \pm 1.14)$ & $106 \mathrm{~b}( \pm 16.72)$ \\
Thousand Grain Wt $(\mathrm{g})$ & $147 \mathrm{a}( \pm 6.38)$ & $25 \mathrm{~b}( \pm 0.00)$ \\
Yield $\mathrm{kg} / \mathrm{ha}))$ & $26 \mathrm{a}( \pm 0.00)$ & $2561 \mathrm{~b}( \pm 9.14)$ \\
\hline
\end{tabular}

Note: Means with same letters for each tested parameter are not significantly different at $5 \%$ probability. Standard deviations are given in parenthesis

\section{CONCLUSIONS}

Poor WM, time of LP, use of rotavators for primary LP and poor quality of seed were identified as the major problems in the area studied. Early LP with onset of RF save $66 \%$ of water from the total WM. LP using tine tiller compared to rotavator reduces the amount of water required for the LP and increase the access to more water and nutrients by increasing the root depth. Tank WP was 1.93 and $0.28 \mathrm{~kg} / \mathrm{m}^{3}$ in treatment and control, respectively. PM with Best management practices such as proper LP, recommended seeds, using organic matter, proper weeding, is important along with the conjunctive use of RF and tank water. Conjunctive use of RF and tank water is most successful in increasing WP of minor irrigation systems in Udakadawala area.

\section{ACKNOWLEDGEMENTS}

Authors would like to thank Mr. Prabhath Vithana, the Chief Engineer, Department of Agrarian Development for his fullest support, Mr. Wijerathna, Jala palaka and Mr. Samarasinghe, Secretary of Farmer organization, Udakadawala Maha Wewa tank for their assistance in this research.

\section{REFERENCES}

Department of Agriculture, (2006). Crop-recommendations /905, Ministry of Agriculture, Sri Lanka. Accessed on $15^{\text {th }}$ January 2013, Available at:

http://www.agridept.gov.lk/index.php/en/crop-recommendations/905,

Department of Agrarian Development, (1991). Agrarian Services (Amendment) Act, No. 4 of 1991. Ministry of Agriculture, Colombo, Sri Lanka.

Dharmasena, P.B. (1989). Optimum utilization of the storage in village tanks. Tropical Agriculturist, 145, 1 - 11.

Madduma Bandara, C.M. (1985). Catchment ecosystems and village tank cascades in the dry zone. Dordecht, Holland: Riedel Publishing Company. 
Thilakasiri et al.

Panabokke, C.R. (1999). Small Tank cascade Systems of the Rajarata settings, distribution pattern and hydrography. International Water Management Institute, Colombo, Sri Lanka.

Samgar, R.S. (2010). Participatory rural appraisal tools and techniques. A Guide to PRA. 